\title{
Equality, Development Equivalence and Federal Finance in Argentina
}

\author{
Miguel Angel Asensio
}

Throughout history, when federal unions have been formed, inequality has characterised their development. Yet, liberty and regional equality have not followed a similar path, as they have been essential but also specific to each of the federate units. Holland in the United Provinces, Prussia in the Germanic Confederation, New York in relation to its counterparts among the US states are clear examples of this. ${ }^{1}$ Unity with diversity or unity and diversity prevail. ${ }^{2}$

If we look back at its origins in the 19th century, the federal formation of Argentina, after some failed or provisional constitutional agreements, is also characterised by large differences between the regional units which signed the Federal Constitution. ${ }^{3}$

Given the ample differences between the federate states regarding aspects such as their respective economy, geography and demography, while the Federal Constitution achieved equality regarding competences and rights, it did not aim at ensuring a similar equivalence regarding the development and opportunities for each state. For instance, even if differences already existed before the independence from Spain in the early 19th century, the gap between the big 'Interior' and the region of the Rio de la Plata has been continually increasing since the Constitutional Agreement, which was achieved in the beginning of

1 Not to mention New South Wales and Victoria in Australia or Central Canada (Ontario and Quebec) vis-à-vis the rest of the country, among others.

2 See Michael Burgess and Alain C. Gagnon, Comparative Federalism and Federation, Competing Traditions and Future Directions (Toronto: University of Toronto Press, 1993); Michael Burgess and Alain C. Gagnon, General Document Presented at the Montreal Meeting of IACFS on Unity and Diversity in Federal Systems (Montreal, 2015). See also Preston King, Federalism and Federation (Maryland: The Johns Hopkins University Press, 1982).

3 The constitutional texts of 1819 and 1826 were rejected by the provinces, and the Federal Pact of 1831 , being relevant as a precedent, had a fragile and incomplete existence previous to the Constitution framed in 1853 . 
the 185 os. $^{4}$ At the present time, more than 160 years later and in spite of some significant variations, these important differences between regions remain. In fact, when the representatives gathered together to approve the last reform to the Argentine Constitution (1994), the personal Gross Domestic Product (GDP) in the wealthiest jurisdiction had reached nine times that of the poorest. ${ }^{5}$ In such a context, the 'equivalent development' and 'equality in the living conditions' were outstanding goals set during the sessions and debates in the Reforming Constitutional Convention, finally incorporated in the accorded text of the Fundamental Law. These goals had to be reached by the revenue sharing regime, a mechanism that would be at the core of the federal fiscal system.

These objectives are explicitly set forth in the Constitutional Document, Art. 75, item 2, stating that 'the distribution among the Nation, the provinces and the city of Buenos Aires and among the latter [...] will be equitable, solidary and shall give priority to the achievement of an equivalent degree of development, quality of life and equal opportunities in the whole national territory'. Despite this, the process of uneven economic growth among regions and provinces has continued and, a quarter of a century after the sanction of the reform of the original Magna Charta, the new revenue sharing system has still not been enacted, except for particular modifications emerging from different Intergovernmental Agreements. ${ }^{6}$

In this chapter, we will produce an analysis in which we will review uneven regional and provincial development, have a closer look at the challenges and limits faced by the federal fiscal system, as well as examine the possibilities available that would make it possible to overcome this uneven development. Throughout this analysis, we will keep in mind the role and

4 See Alberto J. Figueras, "Enfoque regional de la economía argentina: Su estructuración histórica," in El desafío del territorio, Un análisis de las economías regionales, eds. Alberto J. Figueras and José L. Arrufat (Córdoba: Asociación Cooperadora de la Facultad de Ciencias Económicas de la Universidad Nacional de Córdoba, 2007), 37-50. See also Alejandro B. Rofman and Luis A. Romero, Sistema socioeconómico y estructura regional en Argentina (Buenos Aires: Amorrortu, 1974).

5 We refer to the per capita GDP. Alejandro B. Rofman, Las economías regionales (Buenos Aires: Centro Cultural de la Cooperación Floreal Gorini and Universidad Nacional de Quilmes, 2012).

6 The Complementary Clause Six to the Constitution stated that for the year 1996 (two after the sanction of the Reform) a new revenue sharing law should be enacted. The 'patchwork system' was the option instead and no general law for the distribution of taxes among Nation and Provinces was approved. Recently, another Intergovernmental Agreement, regulating partial issues of the multilevel fiscal relationship (the so-called Fiscal Consensus) was signed, the Federal Government and the provincial ones being part of it. 
mission assigned to the federal-fiscal scheme and the complexity of achieving a 'magic formula' embedded in a new revenue sharing system, considering the ambitious objectives stated in the National Constitution. The aim of this chapter is to question the present situation in the Argentinian Federation and demonstrate that other mechanisms should be considered in addition to the sole fiscal formulas aiming at tackling the current uneven development. Concretely, after this brief introduction, we will address the origins of the regional divergences and their significance in the federal association (2). Next, we will consider some regional indicators in order to highlight the current differences and existing asymmetries (3). In doing so, we must bear in mind that the statistics available in Argentina are not up-todate and this chapter should also be regarded as a call urging researchers and the federal administration to update them, in order to attain higher accuracy in the determination of territorial divergences. We will then look at what can be done to achieve 'equivalence in development' and will reflect on this contemptuous issue (4). Then, we will give a more detailed explanation of the previous legal norms that aim to solve the provincial-regional inequalities and the limited outcomes in such a field, as well as the current situation of uneven development (5). Finally, before closing this chapter with our concluding remarks, as an answer to the limitations that we unveiled in the previous sections, we address the need for designing and introducing other instruments of regional policy aimed at changing the unbalanced provincial and regional development of the country.

\section{Growing and Great Divergence}

From the 1820 s onwards, hardly a decade after breaking off its ties with Spain and thus gaining its independence, Argentina began to operate as a loose confederation where the provinces claimed autonomy, with Buenos Aires in charge of international relations, the main seaport and customs. The union between the prosperous Buenos Aires and the poorer 'thirteen huts' ${ }^{17}$ materialised under

7 We allude to the despective denomination given to the rest of the Provinces from centralist and unitarian politicians, media and thinkers of Buenos Aires, in an unequal Union of 14 members which represented in fact the two parts of Argentina in the middle of the 19th century, one rich and prosperous and the others suffering from scarcity of resources. Recently, the expression has been attributed to the famous poet José Mármol: see Julio Pinto and Fortunato Mallimaci, La influencia de las religiones en el Estado y la Nación Argentina (Buenos Aires: Editorial Universitaria de Buenos Aires - EUdEBA, 2013). 
the 1853 Constitution was not only difficult but fragile. After renewed conflicts and some reforms, it was consolidated in 186o-1866.

However, these conflicts concealed the lagging situation of the inland and nonAtlantic regions, which were deprived of their export markets in the North due to the new border that emerged after some incidents and battles of war. The episodes were fuelled again by the divergent interest of Buenos Aires and the other provinces, which conditioned the final agreement. The financial issue, always decisive, implied as a condition the assurance of five years of budget support for the previous 'State of Buenos Aires'8 The supremacy of the National Government was accepted by the other provinces, because it allowed them to maintain the Federal Compact. This ensured the receipt of funds from the Customs Offices, which had been monopolised for decades by the Government of Buenos Aires.

From a territorial point of view, the development of Argentina as a country resulted in permanent loss of economic and demographic importance of the inland regions and a growing significance and power of the Littoral ones. In such a context, the Federal Constitution did not alter the natural competitive advantages of Buenos Aires and - despite a weaker participation of other parts of the Pampean Region - its domination continually increased, while other regions faced a slower economic progression and a demographic weakening. The result of this general tendency was that the main centres of the Interior, particularly Córdoba - located on the ancient trade route between Buenos Aires and the northwest - but also Salta, Tucumán and Mendoza, lost economic weight in the country. Research carried out a few years ago by economic historians analysing data on population, exports and other aspects, reveals the growing importance of the richer region compared to the rest of the country, namely the West, North and South. To illustrate this evolution, Table 8.1 shows the development of the Littoral and Interior until the first decade of the second half of the 19th century, right at the beginning of the Argentine 'golden age'. ${ }^{9}$ From the last half of the 19th century onwards, the process continued and the prosperity of the Pampean Region ${ }^{10}$ and its provinces spread throughout

8 The 'nationalisation' of the Customs Office implies that the taxation provided by foreign trade would be collected by the federal government and not by the Province of Buenos Aires. The Province of Buenos Aires reached a compromise with the Federal Government which must send an annual amount of money to support the budget of the Province for five years.

9 See Ricardo Salvatore and Carlos Newland, "Between Independence and the Golden Age: The Early Argentine Economy," in A New Economic History of Argentina, eds. Gerardo Della Paolera and Alan M. Taylor (New York: Cambridge University Press, 2007), 19-45.

10 In the literature, it is possible to find the words 'Littoral' and 'Pampean' sometimes utilised alternatively. Littoral alludes to coastal regions, maritime or fluvial. In Argentina, one could distinguish the Upper Littoral (to the North of present city of Santa Fe) on the 
TABLE 8.1 Evolution of economic and demographic variables in Argentina in the 19th century

\begin{tabular}{lll}
\hline Variables & $\mathbf{1 8 2 0}$ & $\mathbf{1 8 6 0}$ \\
\hline Population & 477,238 & $1,736,923$ \\
Littoral & 184,822 & 847,518 \\
Interior & 292,416 & 889,405 \\
Urbanisation rate (\%) & $25 \cdot 5$ & 30.4 \\
Littoral & 36.8 & $45 \cdot 7$ \\
Interior & 18.4 & $15 \cdot 9$ \\
Exports & 3,082 & 27,049 \\
\hline
\end{tabular}

the regions, while the Interior faced a situation of stagnating development. From 186 o to 1930 the country followed an export-led model of growth and in the year 1913 it reached the tenth position worldwide in per capita GDP. This period was called the 'golden age' or 'belle époque' by some authors due to the prosperity then achieved and was associated with a strong international insertion in a world economy lead by Great Britain. ${ }^{11}$ In spite of this, the "belle époque' considered as a whole was not a well-balanced process but rather an uneven one. In fact, the growth then achieved was largely concentrated in some specific regions due to the comparative advantages enjoyed by a part of the country, combined with the dynamic export economy well inserted in the international markets. Thus, provinces and regions that enjoyed such a process progressively improved their situation with regard to the other ones, which continued lagging behind.

coast of Parana River and the Lower Littoral (from Santa Fe to Buenos Aires) on the coast of the Parana River and the Rio de la Plata to Buenos Aires approximately. The Lower Littoral or 'Pampean Littoral' coincides with the North of the Pampean Region. This is why an interchangeable denomination appears to refer to that geographical portion of the country, which sometimes extends to the southern part of the present Entre Rios to the coast of the Rio Uruguay (both rivers Parana and Uruguay give existence to the very short and wide Rio de la Plata).

11 For such denomination see Carlos F. Díaz Alejandro, "No Less Than One Hundred Years of Argentine Economic History Plus Some Comparisons," in Comparative Development Perspectives: Essays in Honor of Lloyd G. Reynolds, eds Gustav Ranis, Robert L. West, Mark W. Leiserson and Cynthia Taft Morris (Boulder, Colorado: Westview Press, 1984) 328-361; Salvatore and Newland, "Between Independence and the Golden Age," 19. 
This so-called 'outward-looking' model was followed after the 193os by an 'inward-looking' or 'import-substitution model', reasserted after World War II. World War II, as well as the post-war era, was a period of time that deeply changed Argentina's demography and resulted in a concentration of its population in the prosperous Pampean area. While Argentina had to deal with important internal migration, it encountered massive immigration of foreigners, which increased the impact on the population's repartition inside the country. The society and its economy continued to grow concentrated in the same area, particularly in and around the city of Buenos Aires. There were nevertheless some moderate spill-overs from Buenos Aires to San Nicolás and Rosario, on the Paraná River, which made up the 'industrial belt', on the one hand, while on the other hand, the emergence of Córdoba in the centre of the country appeared as the base for a car-manufacturing hub (thanks to power facilities). ${ }^{12}$

\section{Advanced and Backward Partners}

While Argentina as a federation encompasses some more advanced partners, others appear to be in a more backward position. The facts and results mentioned above can be examined by analysing the temporal variations in the national and regional context using a quantitative approach. We will use the data of the provinces and aggregate them in order to obtain a better overview of the regions they form. It is possible to consider a period of more than half a century from the beginning of the 1950s to the first years of the present century. In this section, we will therefore look at the regions as aggregates of the provinces forming the Federal union, and compare Buenos Aires on its own with the rest of the regions, within the same period of time. What we expect to highlight is the importance of the gap between wealthy, or advanced, and

\footnotetext{
12 The stages and models for considering the economic development of Argentina in a historical perspective are ample. See Aldo Ferrer, Economía argentina, Etapas de su desarrollo y principales problemas (Buenos Aires: Fondo de Cultura Económica, 2009); Carlos F. Díaz Alejandro, Ensayos sobre la historia económica argentina (Buenos Aires: Amorrortu, 1983); Guido Di Tella and Manuel Zymmelman, Las etapas del desarrollo económico argentino (Buenos Aires: Paidós, 1973); Mario Rapoport, Historia económica y social de la Argentina (Buenos Aires: Ariel, 2008); Pablo Gerchunoff and Lucas Llach, El ciclo de la ilusión y el desencanto (Buenos Aires: Crítica, 2015); Eduardo Miguez, Historia económica argentina (Buenos Aires: Sudamericana, 2003); Jonathan Brown, Historia socieconómica del Rio de la Plata (Buenos Aires: Sudamericana, 1998); Gerardo Della Paolera and Alan M. Taylor, A New Economic History of Argentina (New York: Cambridge University Press, 2007).
} 
poor, or backward, partners in the Federation, which is at the core of the proposal calling for a revenue sharing regime with a levelling profile to be adopted in the country (we will examine this proposal in further detail in section 6).

Before elaborating, we shall first emphasise two elements, namely, on the one hand, the meaning and significance of the regions and their relationship with the 'provinces' and, on the other hand, the statistical gaps and limits in the existing data. Regarding the regions, a distinction needs to be made between 'natural regions' and other types of regions. To understand this, we need to go back in time, some decades ago, when Jacques Boudeville offered a now well-known typology, where he classified regions into three categories: 'homogeneous', 'polar' and 'planning' regions. ${ }^{13}$ This proposal influenced the division that was then adopted and that is today commonly used to refer to Argentina's different regions. While the 'homogeneous regions' are closer to the idea of being 'natural' or 'geographic' ones, it is the category of 'planning region' that is more frequently used when it comes to adopting development policies. In Argentina, as in other countries, the regions were originally designated on the basis of their topography, but were then altered for political and administrative reasons to create comparable units. ${ }^{14}$ If we look at the provinces, unlike the regions, they are the original political units which made up the federal state and are not influenced by topographic considerations as they can include a wide range of different natural environments. A group of provinces forms a region; however, it is the region and not the province that is taken into account when adopting development policies and yet, it is the province and not the region that enjoys parliamentary representation on the federal level.

Regarding the statistical limitations we referred to, some of them originated in the past and affect the accuracy of regional economic data today. However, a major limitation that affects scholars from all fields of study analysing the Argentinian case, as well as the federal administration when it has to develop or implement its policies, is related to data on Argentina's GDP. As a matter of fact, there is to this day no up-to-date statistical data measuring the GDP of the provinces or regions. In the years 2006 and 2007, methodological changes were implemented without general technical consensus, weakening the data

13 See Jacques Boudeville, Los espacios económicos (Buenos Aires: EUDEBA, 1967).

14 The 'planning regions' have also been denominated functional regions in the sense that they exist linked to some political proposal. See Carlo Desideri, "Regionalism and Territorial Politics in Italy," in Federalism, Regionalism and Territory, ed. Stelio Mangiamelli (Milano: Giuffre, 2013), 149-196. 
produced and affecting its quality for use as a tool for analysis and interpretation. The present situation resulted not only from methodological changes, but also from a lack of resources that would ensure a systematic collection and treatment of data. While alternative methods might be found by researchers to reach an approximation of the GDP of provinces and regions, there is no reliable and official data after the year 2005. Consequently, we shall take into account these limits - eventually addressing them - without, however, ignoring global trends.

In Table 8.2, we can observe the territorial GDP weight of a grouping of five regions in Argentina, namely, the North West region (NOA) (Jujuy, Salta, Catamarca, La Rioja and Santiago del Estero), the North East region (NEA) (Chaco, Formosa, Corrientes and Misiones), the Cuyo region (Mendoza, San Juan and San Luis), the Pampean region (Buenos Aires, Santa Fe, Córdoba, La Pampa and Entre Rios) and finally the Patagonia region (Rio Negro, Chubut, Santa Cruz, Tierra del Fuego). This classification is in principle the same as that used by the National Institute of Statistics and Censuses (INDEC). ${ }^{15}$ What is striking in this figure is the enormous relative size of the Pampean aggregate of provinces, especially when considering that it additionally includes the СABA and its surrounding area, denominated АмВA. However, if we look at its evolution over time, we can see that the present territorial giant has actually reduced a little of its economic magnitude. In fact, over more than half a century, despite an increase in the 1970s, the Pampean Region has seen its weight in the Argentine economy slowly decline from four fifths of the global size of the national economy to three fourths. ${ }^{16}$

In the rest of the country, there are some compensatory steps toward progress such as the modest but visible ones of the NOA and Cuyo regions, partially counterbalanced by the decline of the NEA region. The clear winner, however, is the Southern Region of Patagonia, whose performance has been sustained, without setbacks. This measurement, however, depends on the importance of the provincial GDP, and does not capture the actual regional incomes absorbed by each jurisdiction. If that were the case, the relevance

15 We are incorporating the Metropolitan Area of Buenos Aires (AMBA), which consists of the Autonomous City of Buenos Aires (CABA) added to its surroundings, within the Pampean, as is frequently done.

16 In the following table we follow the data from Alberto J. Figueras and José L. Arrufat, "La regionalización como respuesta a los desafíos sociales y económicos del Siglo XXI," in $E l$ desafío del territorio, Un análisis de las economías regionales, eds. Alberto J. Figueras and José L. Arrufat (Córdoba: Asociación Cooperadora de la Facultad de Ciencias Económicas de la Universidad Nacional de Córdoba, 2007), 319. 
TABLE 8.2 Economic role of the regions in Argentina (1953-2005, percentage of the national GDP)

\begin{tabular}{lcrrrrr}
\hline Region & $\mathbf{1 9 5 3}$ & $\mathbf{1 9 7 0}$ & $\mathbf{1 9 8 0}$ & $\mathbf{1 9 9 3}$ & $\mathbf{2 0 0 1}$ & $\mathbf{2 0 0 5}$ \\
\hline Pampean & 81 & 81.6 & 78.3 & 77.2 & 76.7 & 74.6 \\
Patagonia & 2.9 & 3.5 & 5.3 & 6 & 6.8 & 8.4 \\
NOA & 6.1 & 5.6 & 6.6 & 6.3 & 6.2 & 6.9 \\
Cuyo & 5.5 & 5.6 & 5.8 & 6 & 5.8 & 6.2 \\
NEA & 4.5 & 3.7 & 4.1 & 4.7 & 4.4 & 4.1 \\
\hline
\end{tabular}

of the highly urbanised CABA area and its surroundings, as well as the whole province of Buenos Aires, would probably be higher. ${ }^{17}$

Table 8.2, above, shows these results, which are the expression of the enormous territorial imbalance, with the Pampean region absorbing three quarters of the total GDP. Figure 8.1 below illustrates this. It shows, on the one hand, the large discrepancy that prevailed consistently in the second half of the last century and, on the other hand, how the correlation between the weaker regions has shifted.

\section{Beyond the Geographic Contiguity: Advanced Provinces in a Different Context}

While the above does not alter the 'geographic continuum', it is however possible to take an alternative regional approach. Since the beginning of the 1970s, Argentina has classified its provinces on the basis of certain main indicators. These criteria made it possible to group them within the whole country according to specific objectives, essentially aimed at supporting federal fiscal decisions and policy changes in intergovernmental finance. Such criteria led to a grouping comprising four types of provinces: a) advanced provinces, b) provinces of low demographic density, c) intermediate provinces and d) backward provinces.

17 It should also be mentioned that this provincial conformation of regions is closer to the idea of territorial 'homogeneity' and contiguity, without omitting polarisation in АMBA; see Francois Perroux, Nota sobre la noción de polo de crecimiento (Buenos Aires: Consejo Federal de Inversiones, 1956). 


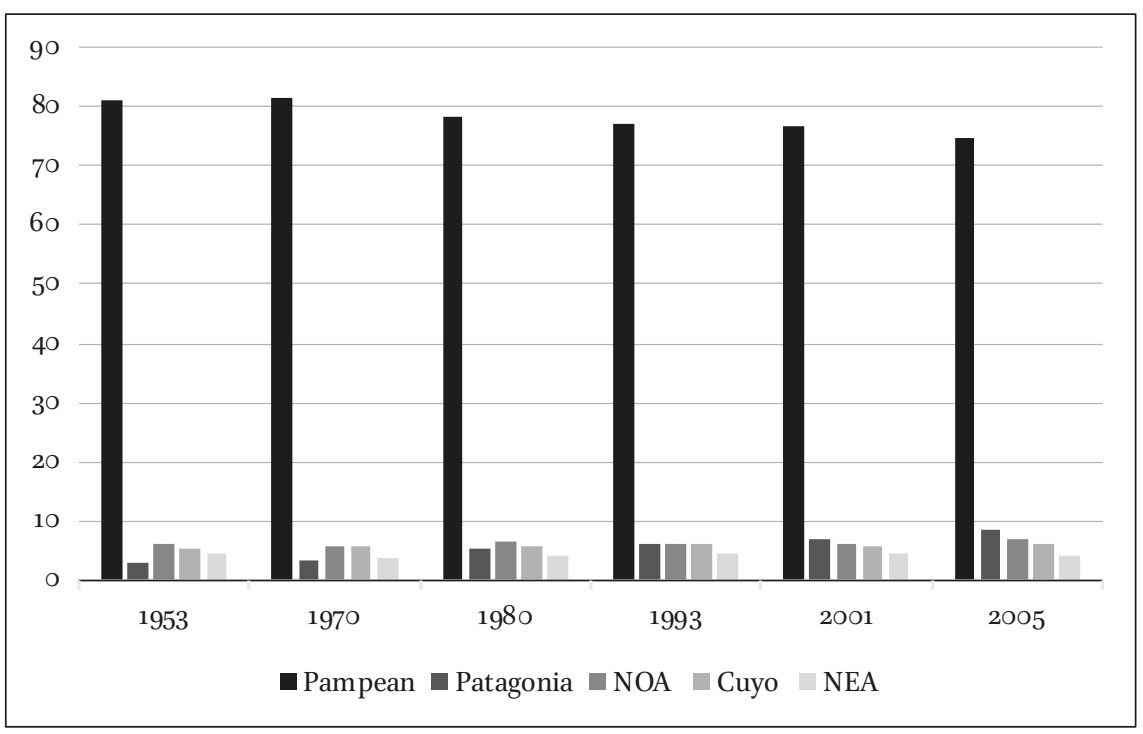

FIGURE 8.1 Weight of the regions in Argentina (1953-2005, percentage of the national GDP)

The so-called 'advanced' regions comprised the main Pampean jurisdictions, as well as the biggest province of the region of Cuyo, Mendoza. The group therefore included the City of Buenos Aires and the Provinces of Buenos Aires, Santa Fe, Córdoba and Mendoza. In view of the long-lasting economic dominance they had over the other provinces of the Argentinian Federation, they are today commonly referred to as the 'traditionally advanced' ones.

Table 8.3 gathers the main results derived from the previously mentioned grouping. Figure 8.2 below shows a non-equivalent but similar conclusion to the previous grouping included in Table 8.2 and Figure 8.1. Why are the results similar, even though we are following an alternative regional classification? This is because the regions considered as 'advanced' in this alternative typology are the bigger jurisdictions like CABA, Buenos Aires, Córdoba and Santa Fe, which are also mainly 'Pampean'. Nevertheless, this alternative classification enables us to highlight some trends in a more detailed way.

In fact, despite lacking more updated statistical information, this new approach makes it possible to highlight the slow but constant increase in importance of the Patagonian Region, or the so-called 'low density' provinces. It also shows the lasting dominance of the Pampean Region, or the most mixed combination of the 'advanced provinces', in spite of a slow reduction in its global weight in the federation. 
TABLE 8.3 Regional development: traditionally advanced provinces and others (1953-2005, percentage of the national GDP)

\begin{tabular}{|c|c|c|c|c|c|c|}
\hline Region & 1953 & 1970 & 1980 & 1993 & 2001 & 2005 \\
\hline Advanced & 81.1 & 82.4 & 80.7 & 78.1 & $77 \cdot 7$ & $75 \cdot 9$ \\
\hline CABA & 31.5 & 33.6 & 30 & $34 \cdot 4$ & $33 \cdot 7$ & $33 \cdot 7$ \\
\hline Buenos Aires & 30 & 29 & 28.2 & 24 & 25.2 & 21.8 \\
\hline Santa Fe & 9.1 & 8.9 & 9.1 & $7 \cdot 9$ & $7 \cdot 4$ & 8.1 \\
\hline Córdoba & 6.6 & 6.7 & 7.6 & $7 \cdot 9$ & $7 \cdot 5$ & 8.1 \\
\hline Mendoza & $3 \cdot 9$ & 4.2 & 4.2 & 3.9 & $3 \cdot 9$ & 4.2 \\
\hline Low Density & $3 \cdot 9$ & $4 \cdot 3$ & 6.2 & 6.8 & 7.6 & $9 \cdot 3$ \\
\hline Chubut & 1 & 1.2 & 1.7 & 1.3 & 1.5 & 2 \\
\hline Santa Cruz & 0.5 & o.6 & 0.7 & 0.9 & 1.2 & 1.6 \\
\hline La Pampa & 1 & 0.8 & 0.9 & 0.8 & 0.8 & 0.9 \\
\hline Rio Negro & 0.9 & 1 & 1.3 & 1.4 & 1.4 & 1.3 \\
\hline Neuquén & 0.4 & 0.7 & 1.4 & 1.7 & 2.1 & 2.8 \\
\hline T. del Fuego & 0.1 & 0.1 & 0.3 & 0.7 & 0.6 & 0.7 \\
\hline Intermediate & 8 & $7 \cdot 5$ & 8.2 & 7.8 & $7 \cdot 4$ & $7 \cdot 3$ \\
\hline San Juan & 1.1 & 0.9 & 1 & 1.1 & 1 & 0.9 \\
\hline San Luis & 0.5 & 0.6 & 0.6 & 1 & 0.9 & 1.1 \\
\hline Entre Ríos & 2.8 & 2.6 & 2.5 & 2.2 & 2.1 & 2 \\
\hline Tucumán & 2.5 & 2.2 & 2.7 & 2 & 1.9 & 1.7 \\
\hline Salta & 1.1 & 1.3 & 1.4 & 1.5 & 1.5 & 1.6 \\
\hline Backward & 7 & 5.8 & 6.6 & $7 \cdot 5$ & 7.2 & $7 \cdot 7$ \\
\hline La Rioja & 0.3 & 0.2 & 0.3 & 0.5 & 0.5 & 0.5 \\
\hline Catamarca & 0.3 & 0.3 & 0.4 & 0.5 & 0.7 & 1.4 \\
\hline Corrientes & 1.4 & 1.4 & 1.5 & 1.4 & 1.3 & 1.2 \\
\hline Jujuy & 0.8 & 0.8 & 1 & 0.9 & 0.8 & 0.8 \\
\hline Misiones & 0.8 & 0.8 & 0.9 & 1.4 & 1.3 & 1.2 \\
\hline Chaco & 1.8 & 1 & 1.3 & 1.3 & 1.2 & 1.2 \\
\hline S. del Estero & 1.1 & 0.9 & 0.9 & 0.9 & 0.8 & 0.9 \\
\hline Formosa & 0.5 & 0.5 & 0.4 & 0.6 & 0.6 & 0.5 \\
\hline
\end{tabular}

In any case, this crude magnitude could not omit the existence of extreme measures which confront the 'have' with the 'have not' provinces and regions. It is very useful to compare the existing differences in the case of the United States of America (USA) with the case of Argentina, employing the 'maximum', 


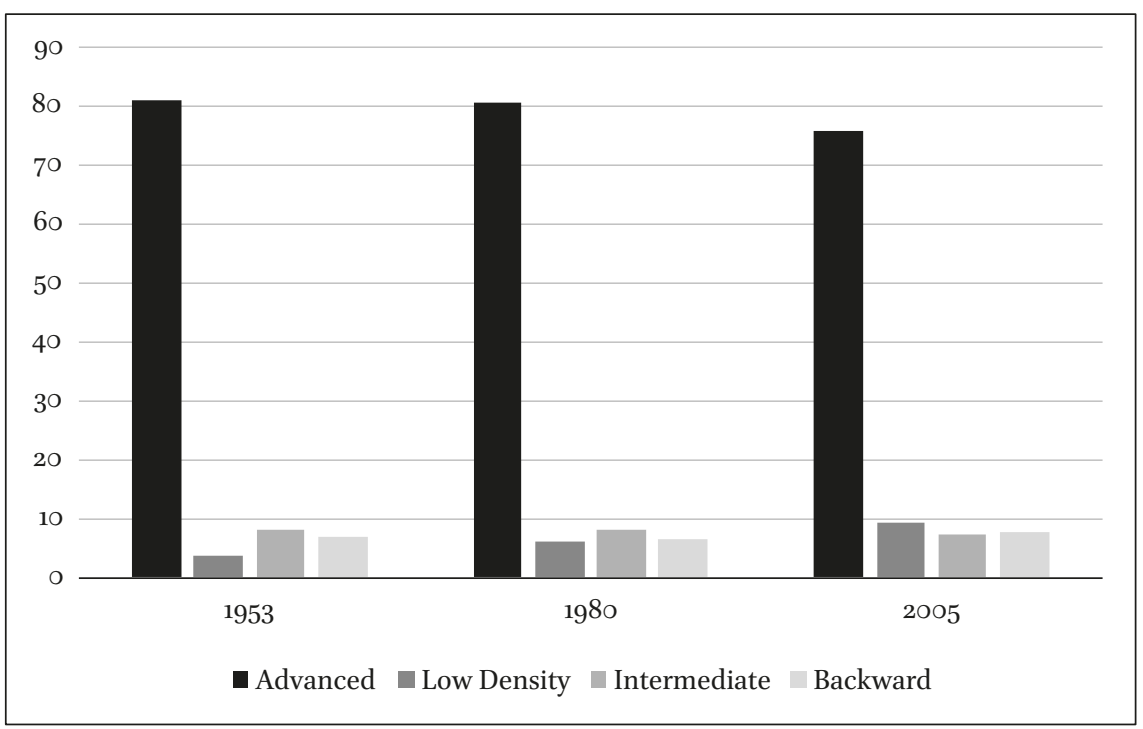

FIGURE 8.2 The 'advanced' jurisdictions and the others (1953-2005, percentage of the national GDP)

'minimum' and 'average' points in terms of personal territorial income among states or provinces (Table 8.4). ${ }^{18}$

Table 8.4 illustrates some striking differences. While the USA has clear regional and national differences, with a ratio of 1.6 times from better to worse, Argentina has more than 8 times the same ratio. In spite of a very modest reduction ( 9 times in the early 199os to 8 times in the last estimation of per capita provincial GDP), the differences continue to be extensive, as the poorest territories have a long 'economic distance' to the richest territories.

\section{$5 \quad$ Equivalence about What?}

Although the idea of 'equivalence in development' is important in itself, it also poses difficulties, especially when it comes to sound and credible measures

18 Source of the following table: USA; BEA (Bureau of Economic Analysis, US Department of Commerce), Paper by Bettina Atten et al, August 2016. Argentina; Author, based on Miguel A. Asensio, "Political Unity and Economic Diversity in the Argentine Federation," in Revisiting Unity and Diversity in Federal Countries: Changing Concepts, Reform Proposals and New Institutional Realities, eds. Alain G. Gagnon and Michael Burgess (Leiden and Boston: Brill-Nijhoff, 2018), 199. 
TABLE 8.4 Regional-provincial divergences: the USA and Argentina

(Index numbers: average $=100$ )

\begin{tabular}{llll} 
USA states & $\begin{array}{l}\text { Per capita } \\
\text { income }\end{array}$ & $\begin{array}{l}\text { Argentine } \\
\text { provinces }\end{array}$ & $\begin{array}{l}\text { Per capita } \\
\text { income }\end{array}$ \\
\hline Highest & 132.6 & Highest & 317.8 \\
Average & 100 & Average & 100 \\
Lowest & 84.4 & Lowest & 39.3 \\
\hline
\end{tabular}

capable of supporting and sustaining appropriate policy decisions and definitions. It encompasses problems of a technical nature, not to mention the complex issue of adopting a unified concept of 'development' as such, which frequently involves questions of normative dimensions. As we know, the definition of growth and development is subject to intense debates and an acceptable definition has yet to be established.

We have recently introduced some available indicators expressing differences, whose consideration confirms the above-mentioned observation. ${ }^{19}$ The difficulties in defining policies and concepts increase when the gap appears between those that were based only on so-called 'crude' economic indicators and those that mobilise indicators that also contain or mix social components. Thus, when dealing with the problem of approaching equivalence in the level of development, GDP can be evaluated with the additional and parallel consideration of other alternative measures, such as the well-known Human Development Index (HDI) or the Coverage of Basic Needs Index (CBN). In addition, the benchmark could be some leading province or region, or even the national average. The first option could be to display something like 'guides and trailers', like an ideal blueprint that should then be adapted to the local reality, to its specific context and constraints. A second option could be to display the distance to the desired minimum. Hence, Table 8.5 shows the 'distance' of provincial indexes with respect to national averages.

Quite unexpectedly, the alternative indicators exhibited in Table 8.5 showed that, given the reduction in the differences detected by examining the jurisdictional outcomes obtained from employing CBN or HDI, any future reform would have to take care of 'something more' than only the per capita GDP as determinant of development.

\footnotetext{
19 Asensio, "Political Unity and Economic Diversity," 193-205.
} 
TABLE 8.5 The search for equivalence: distance from the national averages in three indicators [National average $=100(\mathrm{GDP}$ 2005; CBN 2010; HDI 2006)]

\begin{tabular}{|c|c|c|c|}
\hline Provinces & GDPpc & $\mathbf{C B N}$ & HDI \\
\hline Buenos Aires & $-10,7$ & $+1,5$ & $-1,5$ \\
\hline CABA & $+217,8$ & $+6,3$ & $+5,8$ \\
\hline Catamarca & $-30,0$ & $-2,4$ & $-1,2$ \\
\hline Córdoba & $-7,9$ & $+4,3$ & $+1,2$ \\
\hline Corrientes & $-5^{2,5}$ & $-8,2$ & $-3,3$ \\
\hline Chaco & $-56,2$ & $-12,2$ & $-4,5$ \\
\hline Chubut & $+19,2$ & $+2,1$ & $-0,3$ \\
\hline Entre Ríos & $-29,0$ & $+1,0$ & $-1,2$ \\
\hline Formosa & $-6 \circ, 7$ & $-14,5$ & $-6,8$ \\
\hline Jujuy & $-49,8$ & $-6,4$ & $-2,5$ \\
\hline La Pampa & $-1,1$ & $+7,8$ & $+1,1$ \\
\hline La Rioja & $-38,8$ & $-3,4$ & $-1,5$ \\
\hline Mendoza & $-10,2$ & $+2,5$ & $+0,5$ \\
\hline Misiones & $-47,3$ & $-7,5$ & $-3,8$ \\
\hline Neuquén & $+32,7$ & $+O, 1$ & $+2,2$ \\
\hline Río Negro & $-2,9$ & $+0,9$ & $-1,2$ \\
\hline Salta & $-5^{2,2}$ & $-12,8$ & $-4,1$ \\
\hline San Juan & $-43,1$ & $-10,7$ & $-2,8$ \\
\hline San Luis & $-6,4$ & $+2,1$ & $-1,7$ \\
\hline Santa Cruz & $+64,2$ & $+3,2$ & $+2,8$ \\
\hline Santa Fe & $-6,1$ & $+3,4$ & $+0,5$ \\
\hline Sgo. del Estero & $-58,5$ & $-11,7$ & $-5,4$ \\
\hline Tierra del Fuego & $+96,6$ & 2,3 & $+4,4$ \\
\hline Tucumán & $-45,8$ & $-4,5$ & $-2,7$ \\
\hline
\end{tabular}

\section{The Legal-Constitutional Way - From 'Gap of Development' to 'Equivalent Development'}

The problem of uneven development raises questions with respect to equality between citizens living in different parts of the territory and the needed increase of equilibrium in the federal spectrum. In fact, regional imbalance impacts the 'federal balance'. This issue affects the design and objectives of the federal fiscal 
system. In spite of its partial nature, such a fiscal system will endure pressure so that it increases its ability to reach the general objective of a larger regional balance, which is achievable if it is combined with a multiplicity of other political tools.

The last encompassing federal fiscal legislation was enacted half a century ago, regulating the revenue sharing system in Argentina, which explicitly enhanced the importance of redistribution. Thereby, not only proportional (devolutive) indicators were employed but also redistributive ones. It must be recalled that the revenue sharing mechanism operating with modifications since the $193 \mathrm{Os}^{20}$ implies two types of distribution of the revenue collected from national taxes: ${ }^{21}$ the first one, primary distribution, consists of a distribution between the Federal Government and the Provincial ones; the second one, secondary distribution, is the distribution among provinces of the provincial share. The focus was placed on secondary distribution, with the idea of balancing out inequalities of development on the territorial level, introducing redistributive mechanisms of pro rata sharing among provinces. This was done in order to address the notion of brecha de desarrollo ('development gap') and thus incorporated the formula in the law 20.221 (1973). In view of the indicators and coefficients then available, proportional and redistributive formulae were further considered and incorporated. ${ }^{22}$

Article 3 of the law stated that 'the distribution among the provinces [...] shall be effectuated in accordance with the following criteria: a) Directly proportional to the population, sixty five per cent $(65 \%)$; b) In per capita proportion to the gap of development between each province and the more developed area of the country [...] twenty five per cent ( $25 \%)$; and c) To the provinces which do not have a population density higher than the average of the whole of the provinces, in proportion to the difference between the population density of each province and the mentioned average, ten per cent (10\%)'. Article 4 immediately solved the problem of clarifying the concept of 'gap of development' stating that '[...] it must be understood as gap of development of each

20 Since the constitutional agreement reached in 1853-6o, different periods of evolution in the federal fiscal system have been highlighted: b) concurrency of sources until 1930s; c) revenue sharing from 1930s onwards; a) separation of sources until 189o. Horacio Núñez Miñana, Finanzas Públicas (Buenos Aires: Editorial Macchi, 1994).

21 We have exposed with more detail such a system in previous works. See Miguel A. Asensio, Federalismo fiscal, Analisis. Fundamentosycaso argentino (Buenos Aires: Ciudad Argentina, 200o); Miguel A. Asensio, Local Government Finance in Argentina (Washington: The World Bank, 2006); Miguel A. Asensio, "Subnational Tax Powers in Argentina," Occasional Paper $\mathrm{N}^{\circ} 16$ (Ottawa: Forum of Federations, 2015). 
province the difference in percentage between its level of development and the pertaining to the area which embraces the Federal Capital and the Province of Buenos Aires. For the determination of the development level of each province, it will be applied the simple arithmetic average of the following indexes: a) Housing quality, following the last Housing National Census; b) Level of education of the human resources, following the last National Population Census; and c) Automobiles per inhabitant, belonging to the year in which the last National Population Census was conducted.' The legislator sought to remedy the lack of statistical data on the real personal income of the provinces or GDP per capita on a territorial basis by taking alternative measures aimed at quantitatively approximating the similarities and differences between the provinces. Considering that the differences related to the area of the Capital and Province of Buenos Aires, the redistributive fiscal impact was noticeable.

The need of 'closing the gap' with regards to provincial imbalances was related to another objective, namely the one of 'getting equality in the delivery of public services in the different provinces'. ${ }^{23}$ This last objective is more pragmatic than the former. ${ }^{24}$ The results, in terms of coefficients of secondary distribution among provinces, were favourable to the less advanced ones. The design which was then achieved reached a higher fiscal redistributive profile, reinforced by the creation of an additional institution, known as Fondo de Desarrollo Regional (Regional Development Fund), which reserved $3 \%$ of the national taxation fund to be assigned to developmental projects in the whole country, aiming at the same objective of territorial-regional-provincial development for the underdeveloped regions. ${ }^{25}$ However, while maintaining the

23 Alberto Porto, "Análisis comparado de las finanzas de los gobiernos provinciales en la Argentina," in Finanzas Públicas y Desarollo Regional, ed. Luis E. Di Marco (Córdoba: Dirección General de Publicaciones de la Universidad Nacional de Córdoba, 1989), 227.

24 Curiously, this is the constitutional axis for the definition of the equalisation fiscal system in Canada. See Porto, "Análisis comparado de las finanzas de los gobiernos provinciales en la Argentina," 227; Richard M. Bird, Federal Finance in Comparative Perspective (Toronto: University of Toronto Press, 1986); Bev Dahlby and Joanna Roberts, "Fiscal Federalism and Equalization in Canada," in Federalismo fiscal, Experiencia nacionaly comparada, eds. Miguel A. Asensio and Pablo M. Garat (Santa Fe: Rubinzal y Culzoni, 2011), 295-320.

25 In stricter terms, primary distribution, which mainly divides the bourse between the Federal Governments and the Provinces, also devoted a minor part to the Fondo de Desarrollo Regional. Thus, the Law assigned $45 \%$ to the Federal Level, $45 \%$ to the Provinces and $3 \%$ to the mentioned Fund. In such a way, the redistributive or equalising objective was pursued by redistributive coefficients in the secondary distribution and by specific developmental projects financed by the Fondo de Desarrollo Regional (FDR). 
redistributive pro rata in secondary distribution, the primary distribution was weakened in the early 1980 s by a 'puncture in the bourse' whose revenue was assigned to an unexpected partner: the social security system whose contributions, previously ensured by the business sector, had been eliminated for reasons of competition. This 'puncture in the bourse' that saw resources being redirected from the primary distribution into the social security system is now commonly referred to in Argentina as 'pre-coparticipation'. The direct consequence of this happening was that the core of the original system, which aimed at reducing the 'gap of development', was disrupted after only eight years. ${ }^{26}$

From 1988 on, the later known system of revenue sharing was introduced as a technical alternative, which was implemented in Argentina a decade and a half later than provided for by Law 20.221. As already mentioned, it maintained the revenue sharing regime and the classic profile of two main types of distributions, the primary one and the secondary. The difficulties arose when the last one was designed. In fact, when enacting the secondary distribution, in spite of establishing a new pro rata system among the provinces, the legal text did not show explicit indexes or coefficients of an objective nature supporting the pro rata method. ${ }^{27}$ As Table 8.6 shows, the clear loser was the Province of Buenos Aires and the winners were the large majority of provinces. In that sense, one could say that there was a territorial redistribution of the 'fiscal pool', which later caused recriminations from the affected big province. In addition, another important modification occurred, namely the elimination of the Fondo de Desarrollo Regional and its replacement by another fund. It was denominated Fondo de Aportes del Tesoro Nacional (National Treasury Grants Fund), which supported different objectives, such as the need to provide aid to Provinces suffering or having been affected by financial or emergency circumstances. ${ }^{28}$

During the 1990s, the corrections made on that regime were imposed, like in the past, by the 'social security issue' and other key issues such as the Patagonian demands, the situation of the Buenos Aires conurbation, and a number of other, smaller conurbations. The problem of those issues underlying the corrections made to the regime, is that the corrections did not explicitly consider the regional imbalance as a very long-term and essential issue

26 Enacted by Law 22.293. The same legal instrument imposed an elevation of the VAT's compensatory tax rate which failed to achieve the full compensatory objective.

27 Enacted by Ley 23.548/88, called 'Regimen Transitorio de Distribución de Recursos Fiscales entre la Nación y las Provincias'.

28 The primary distribution assigned 56,66 \% of tax revenues for Provinces, $42,34 \%$ for the Federal Government and $1 \%$ for the Fondo de Aportes del Tesoro Nacional. 
TABLE 8.6 1988: A new attempt for Argentina's regional redistribution through the revenue sharing system

\section{Provincial Jurisdictions $\quad$ Law 20221/73 Law 23548/88 Differences}

\begin{tabular}{|c|c|c|c|}
\hline CABA & -- & 1.4 & 1.4 \\
\hline Buenos Aires & $27 \cdot 99$ & 21.5 & -6.49 \\
\hline Catamarca & 1.93 & 2.86 & 0.93 \\
\hline Córdoba & 8.9 & 9.22 & 0.32 \\
\hline Corrientes & $3 \cdot 79$ & 3.86 & 0.07 \\
\hline Chaco & 4.13 & 5.18 & 1.05 \\
\hline Chubut & 1.86 & $1.5^{2}$ & -0.34 \\
\hline Entre Rios & $4 \cdot 5^{6}$ & 5.07 & $0.5^{1}$ \\
\hline Formosa & 2.29 & 3.78 & 1.49 \\
\hline Jujuy & 2.21 & 2.95 & 0.74 \\
\hline La Pampa & 1.8 & 1.95 & 0.15 \\
\hline La Rioja & 1.72 & 2.15 & 0.43 \\
\hline Mendoza & $4 \cdot 73$ & 4.33 & -0.4 \\
\hline Misiones & 2.96 & $3 \cdot 43$ & 0.47 \\
\hline Neuquén & 1.72 & 1.68 & -0.04 \\
\hline Rio Negro & 2.29 & 2.62 & 0.33 \\
\hline Salta & $3 \cdot 74$ & 3.98 & 0.24 \\
\hline San Juan & 2.55 & $3 \cdot 5^{1}$ & 0.96 \\
\hline San Luis & 1.75 & 2.37 & 0.62 \\
\hline Santa Cruz & 1.44 & $1.5^{2}$ & 0.08 \\
\hline Santa Fe & 9.06 & 9.28 & 0.22 \\
\hline Santiago del Estero & 4.01 & 4.29 & 0.28 \\
\hline Tucuman & 4.55 & 4.94 & 0.39 \\
\hline Tierra del Fuego & -- & 0.7 & 0.7 \\
\hline Total & 100 & 100 & --- \\
\hline
\end{tabular}

to be addressed for the country's development and conformation. ${ }^{29}$ This nonconsideration for the regional imbalance question was confirmed when, in the

29 We have called the period between the last decade of the 2oth century and the beginning of the 21st century the 'era of the Pacts', given that over the regime designed by Law 23.588 different modifications across Fiscal Pacts among Nation and Provinces were superimposed; see Miguel A. Asensio, Descentralización fiscal en el Cono Sury la experiencia internacional (Buenos Aires: Buyatti, 20o6). 
early 199os, the pre-coparticipation instruments for funding the social security system were reinstated, altering the operation of the territorial redistributive coefficients, which had been approved in the 1988 legislation for the secondary distribution in the revenue sharing scheme. ${ }^{30}$ Shortly afterwards, in 1994, the National Convention approved the Reformed Constitutional Text, which again brought up the redistributive objective stating the need for a renewed revenue sharing regime which aimed at equivalent development and related goals as 'equivalence in the quality of life' and 'equality of opportunities' in the whole national territory.

Considering the time span elapsed from 1973 (Law 20.221) to 1994 (National Constitution), we can notice a change in the formulation used to refer to the fiscal regime's aspiration. In fact, while 'gap of development' was initially commonly used, 'equivalent development' was later imposed. Both wordings express the need and aspiration of transferring fiscal resources from rich regions and provinces to the less favoured ones. Art. 75 of the Constitution, as its reading reveals, clearly states that:

[...] The sharing among the Nation, the provinces and the city of Buenos Aires, and in turn among the latter, will be effectuated [...] considering objective criteria for sharing, it will be equitable, solidary (supportive) and will give priority to achieving an equivalent degree of development, quality of life and equality of opportunities in the whole national territory. ${ }^{31}$

Unfortunately, following much economic turmoil, including the 2002 national insolvency, only provisional instruments were designed and adopted (Table 8.7), without complying with the constitutional mandate to enact a new revenue sharing arrangement that would take into account the redistributive goals imposed by the National Constitution as the supreme law and based on 'objective coefficients', as mentioned above.

Today, despite almost 25 years having passed since the approval of the 1994 constitutional mandate - which sanctioned a new regime aiming for objectives like equivalent development, quality of life and equality of opportunities - the whole system is still characterised by imperfect conformation and the implementation of its institutional framework undoubtedly needs to be improved. In any case, the question remains as to how such an ambitious goal like the achievement of an 'equivalent level of development' can be reached,

30 Intergovernmental Agreements of 1992 and 1993.

31 Emphasis added by the author. 
TABLE 8.7 Closing the gap? The legal winding road to 'Equivalent Development'

\begin{tabular}{|c|c|c|}
\hline Date & Normative body & Characteristics \\
\hline 1973 & National Law 20221 & $\begin{array}{l}\text { Revenue Sharing considering explicit } \\
\text { redistributive coefficients based on } \\
\text { 'brecha de desarrollo' (development gap). }\end{array}$ \\
\hline 1980 & National Law 22.293 & Introduces detractions for Social Security. \\
\hline 1988 & National Law 23.548 & $\begin{array}{l}\text { Revenue Sharing without objective } \\
\text { coefficients for sharing and redistribution } \\
\text { without technical sustain. }\end{array}$ \\
\hline 1990/94 & $\begin{array}{l}\text { National Law } 23548 \\
+ \text { Intergovernmental } \\
\text { Agreements }\end{array}$ & $\begin{array}{l}\text { Important pre-coparticipation detractions } \\
\text { from the taxation bag for the Social } \\
\text { Security System. }\end{array}$ \\
\hline 1994 & $\begin{array}{l}\text { National Constitution } \\
\text { Reformed }\end{array}$ & $\begin{array}{l}\text { Imposes the sanction of a new revenue } \\
\text { sharing regime, based on objective } \\
\text { sharing criteria aimed at 'equivalent } \\
\text { development'. }\end{array}$ \\
\hline $\begin{array}{l}1994 / \\
2017\end{array}$ & $\begin{array}{l}\text { Intergovernmental } \\
\text { Agreements deferring } \\
\text { Constitutional } \\
\text { Mandate for new } \\
\text { revenue sharing }\end{array}$ & $\begin{array}{l}\text { Provisional system 'patchwork type' } \\
\text { including the redistributive prorate from } \\
\text { Ley } 23548 \text { applied on a reduced taxation } \\
\text { base or 'tax bag'. }\end{array}$ \\
\hline
\end{tabular}

a question that is even more relevant if we consider the ability of the Federal Financial Regime, ineffective when it comes to revenue sharing. In other words, could the fiscal mechanism of revenue sharing on its own meet this objective?

\section{$7 \quad$ Regional Policies Again, Fiscal and Non-Fiscal Ones ${ }^{32}$}

The problems mentioned above reinforce the need to emphasise the importance of sound regional policies. Such regional policies must be understood

32 To have a deeper understanding of the importance of regional policies in a context of territorial imbalances, see Miguel A. Asensio, "Territorial Imbalances and Regional Disparities within a Federal Context: The Case of Argentina," in Federalism, Regionalism and Territory, ed. Stelio Mangiamelli (Milano: Giuffre, 2013), 93-105. 
as a set of instruments going beyond only one fiscal instrument, in order to improve the reduction of asymmetries in the Argentine federal scheme's functioning. Regional-territorial policies are essential, not only in Argentina, but in any federal organisation. This is of particular importance when a concentration process ${ }^{33}$ and economies of agglomeration - in other words, 'agglomeration effects' - have occurred over many decades, ${ }^{34}$ based on mechanisms like the 'cumulative circular causation' which predominantly favours some portion of the territorial space of a country. ${ }^{35}$

In view of the above situation in which the Argentinian Federation finds itself, we will present in this section some relevant policies that could be implemented to support the overall effort of addressing the uneven development. We will allude to some relevant policies at the regional level, rather than those on the national level, because we consider the regional level as an environment close to the people, where policies can be tested and improved. Of course, it is possible to imagine new fiscal equalisation processes - or improve existing ones - on the national level. It is good and important to improve the fiscal regime and the revenue sharing mechanism, yet we consider that federal policies should be supported by regional policies. We strongly believe that mechanisms on the national level would profit from inputs, best-practices and knowledge gathered by regional authorities through locally implemented development mechanisms.

On the one hand, regarding fiscal measures, we propose two alternatives, which differ from the mere equalisation or revenue sharing with redistributive prorate. The first are the budgetary spending and budgetary allocations, which could acknowledge internal varieties from investment projects, public works, transfers or assignments. These allocations are aligned differently depending on the regions. The second, the so-called tax expenditures or fiscal stimulus, are aimed at promoting the development of the stagnant or less dynamic territorial areas. If these mechanisms have any limitations, they

33 Francois Perroux has reminded us that 'economic growth does not occur in all points and at the same moment, but the opposite', considering points as equivalent to industrial branches, sectors and regions; Perroux, Nota sobre la noción de polo de crecimiento.

Or more prolonged spaces of time, like in Europe, as is documented in Juán R. Cuadrado Roura and Tomás Mancha Navarro, "Política regional y de cohesión," in Economía de la Unión Europea, ed. Josep M. Jordán Galduf (Madrid: Thompson-Civitas, 2008), 465-514. The theory of 'cumulative circular causation' was developed by Gunnar Myrdal to describe concentrated regional economic growth. See Gunnar Myrdal, Teoría económica y regiones subdesarrolladas (México: Fondo de Cultura Económica, 1957), with English Version as Gunnar Myrdal, Economic Theory and Underdeveloped Regions (London, Methuen Paperbacks, 1957). 
are to be found in the relation between the revenue cost and the outcomes achieved. ${ }^{36}$

On the other hand, regarding financial measures and credits, we shall first highlight the fact that some have already been regulated by monetary authorities in order to support specific regions. In Argentina, the central bank established one monetary mechanism, which involved loans made by private and commercial banks and not by the central bank directly. ${ }^{37}$ Those loans are however short term ones, while development needs to be planned on the long term. An alternative would be to implement financial measures and credits that would involve a variety of specific loans aiming at development. Such specific loans would need differential lapses for repayment in the long term, enabling more flexibility and avoiding the constraints imposed by the short term. They would also be characterised by differentiated rates of interest and frequently involve subsidies for the selected territorial areas. They would require the creation of specific institutions like development banks which are guided by such objectives. These institutions and corporations operate in national contexts, as well as in the international arena, the Brazilian Banco Nacional do Desenvolvimento, the World Bank and EUBI (European Bank for Investments) being outstanding examples. However, this kind of measures linked to the banking system, even if their objective is development, are not free from controversies. They need to be monitored and it has to be insured that political or private interests, among others, which could jeopardise the development of the targeted regions, do not bias them.

Furthermore, it is necessary to mention the importance of regulations for regional development policies. According to the definition given by the Economic Council of Canada 'regulation is defined as government imposition of rules and controls designed to direct, restrict or change the economic

36 The underlying culture that conditions the way economic and political problems are dealt with must also be taken into account when planning development policies. Regional problems are very difficult to deal with and overcoming them needs planning in the short term, middle term but most of all in the long term. For uneven development to eventually be overcome inside a Federation, the differences that can exist in the underlying problem-solving culture of the different federate states needs to be addressed. For an illustration of this argument, see Vittorio Marrama: Política económica y países subdesarrollados, (Madrid: Editorial Aguilar, 1961); Elena Rodríguez, “Commentary," Desarrollo Económico, Vol. I, $\mathrm{N}^{\circ} 3$ (October-December 1961): 217-219.

37 This mechanism had at its core the reduction of the Cash Deposit Ratio (CDR), which can be understood as an amount of minimum cash private banks must effectively possess. Being a percentage of the overall amount of money being lent, when the CDR is relaxed by the central bank, it allows the private banking system to lend more. 
behaviour of individuals and business, and these rules and controls are supported by sanctions and penalties for non-compliance. ${ }^{38}$ In fact, regulations and controls, together with procedures, monitor the efficiency and competitiveness of such important activities as those of big business with extended territorial dimensions, public services, transport activities, natural monopolies and public utilities, and thus are bound to have a regional impact. Increased competitiveness of regions is perhaps one of the most important outcomes of policy decisions. Therefore, regulation and deregulation are not neutral in relation to the development of regions, provinces, districts and cities. If well designed they could improve and foster the economic and commercial position of such territorial areas, given a good institutional framework and practices of public bureaucracies and governance. ${ }^{39}$

Regarding the issue of competitiveness, a number of regional policies are linked to public and private capacity building and distribution. Such capacities need to be included in the concept of regional (or provincial) competitiveness. The regional imbalances could be overcome by improving the competitiveness of less advanced regions vis-à-vis the developed ones. In this way, it could be possible to foster a balanced federalism with regional balance across regional policy itself, and to combine fiscal and non-fiscal measures. Achieving this is not an easy task, as shown by continuous efforts in developed federal countries or the European Union. ${ }^{40}$ But 'difficult' is not equivalent to 'impossible'. The Argentinean constitutional objective of achieving a more equal (or less unequal) territorial and provincial development in the sense of 'equivalence at the stage of development' must be included in such a broadened perspective.

As can be observed from the data mentioned above, Argentina has presented - since more than a century and a half - a very particular and unique case of demographic and economic concentration in the city of Buenos Aires and the surrounding area, which conditions and influences the unequal

38 John C. Strick, "Regulation and Deregulation," in The Handbook of Canadian Public Administration, ed. Christopher Dunn (Toronto: Oxford University Press, 2002), 263-278.

39 The creation of bodies or agencies to foster progress as institutional devices for territorial development has been mentioned as third generation measures for regional growth. See Bert A.H.J Helmsing, "Teorías del desarrollo industrial regional," Revista eure, Vol. xxv, $\mathrm{N}^{\circ}$ 75 (September 1999): 5-39.

40 Here, we allude to the strategy based on the 'structural funds' and correlative measures, whose objective is the reduction of differences between the member States. For the case of Canada, see James P. Bickerton, "Regional Development in Canada: Fifty Years of Federal Policies and Agencies," International Meeting on Economic and Institutional Trajectories in Federal Countries, March ${ }_{30-31}$ (Santa Fe, Argentina: International Meeting on Economic and Institutional Trajectories in Federal Countries, 2016). 
federation. This inequality does not only relate to development, but also to sociology, culture, political organisation, electoral weight and so on. This essential aspect has been addressed many times throughout history, including recently. As I have mentioned in previous works, ${ }^{41}$ Buenos Aires was accused of 'macrocephaly' in the face of a nation with a huge and disproportionate head and a fragile and weak body. There is a quotation widely known among Argentinians, attributed to the French Minister of Culture André Malraux who visited Argentina in the 1960s, that says 'Buenos Aires is the Capital of an Empire that never existed. ${ }^{42}$ His compatriot, the famous French politician George Clemenceau had also eulogised the capital half a century earlier as he visited Argentina in 1910 for the country's centennial celebration and named Buenos Aires a 'great city', 'one like a great city of Europe..43 That was however in more prosperous times, when the level of personal income in the country corresponded to that of advanced nations. ${ }^{44}$ Today the metropolitan city continues to be enormous, despite changed conditions and sluggish economic growth. Buenos Aires and its surroundings represent a weight of ten times the population of the next largest cities, Córdoba and Rosario. Attempts to limit the growth of the capital city by changing the location of the central administrative units (establishing a new capital for Argentina) have failed. ${ }^{45}$

Several of the regional policies mentioned above have been implemented with time: fiscal incentives, ${ }^{46}$ national and provincial development

41 For further information, see Miguel A. Asensio, "Territorial Imbalances and Regional Disparities within a Federal Context: The Case of Argentina," in Federalism, Regionalism and Territory, ed. Stelio Mangiamelli (Milano: Giuffre, 2013); Miguel A. Asensio, Local Government Finance in Argentina (Washington: The World Bank, 2006); Miguel A. Asensio, "Subnational Tax Powers in Argentina," Occasional Paper $N^{\circ} 16$ (Ottawa: Forum of Federations, 2015); Miguel A. Asensio, "Political Unity and Economic Diversity in the Argentine Federation," in Revisiting Unity and Diversity in Federal Countries: Changing Concepts, Reform Proposals and New Institutional Realities, eds. Alain G. Gagnon and Michael Burgess (Leiden and Boston: Brill-Nijhoff, 2018).

This expression is deeply rooted in Argentina's present memory. It inspired the title of book by Horacio Vázquez Rial, Memoria de las ciudades. Buenos Aires 1880-1930. La capital de un imperio imaginario (Madrid: Alianza Editorial, 1996).

43 For further information on Clemenceau and Argentina at the beginning of the 2oth century, see Richard J. Walter, Politics and Urban Growth in Buenos Aires: 1910-1942 (New York and Cambridge: Cambridge University Press, 1993).

44 For similar comments on this same issue, please consult the famous historian Félix Luna, who wrote Buenos Aires y el país (Buenos Aires: Sudamericana, 1978).

45 Such attempts already started in the 19th century, all without success.

46 The so called 'Leyes Nacionales de Promoción Industrial', during and after the 195os targeted some specific territorial resources, such as the resources from the Province of Tierra del Fuego, in the extreme South of the country. 
banks, ${ }^{47}$ infrastructural projects, etc. Because those policies either have sometimes failed or had rather modest results, the Constitution reaffirmed the proposal of pursuing the objective of equalisation by means of the previously mentioned revenue sharing mechanism. Even an equalising task for the budget was considered, in its expenditure side, under the same philosophy. ${ }^{48}$ In any case, however, the current outcomes do not look very strong and it seems that natural resources are the real force fuelling the changes such as those observed in the Patagonian evolution. ${ }^{49}$

Additionally, some studies have demonstrated existing divergences in provincial capacities, expressed in different indices showing a significant gap between the main geographical units and those that do less well when it comes to competitiveness. The global index for Santa Fe is in fact three times that of Chaco and the index for Buenos Aires is twice as high as that of Formosa. ${ }^{50}$

In this chapter, we have tried to address the difficulties and challenges that emerged in Argentina when the country intended to meet the objectives that were stated in the modern constitutional text. These objectives, contained in the version approved in 1994, established the mechanism of revenue sharing as the axis of the fiscal federal system, and aimed at achieving equity and equivalent development in the Nation..$^{51}$ Given that these goals would be incorporated in the much delayed reform to the needed legislation, some considerations are revised as an enlarged analysis of previous contributions to the territorial divergences of the country. In the constitutional system of

47 On the national level, the 'Banco Nacional de Desarrollo', created in 1971 and closed in the 199os under claims for inefficiency and corruption. In the Province of Santa Fe, the 'Banco Santafesino de Inversión y Desarrollo', also existed until the 199os.

48 Art. 75, section 8, National Constitution.

49 On this topic also Equality and Advantage in Emerging Federations and the Dilemma of Non-Renewable Natural Resources: the cases of the Solomon Islands and Trinidad and Tobago by Nico Steytler (chapter 7).

50 See Alberto J. Figueras, "La competitividad de las economías provinciales," in El desafío del territorio, Un análisis de las economías regionales, eds. Alberto J. Figueras and José L. Arrufat (Córdoba: Asociación Cooperadora de la Facultad de Ciencias Económicas de la Universidad Nacional de Córdoba, 2007), 296.

51 The Federal Constitution established qualitative conditions not only for the legislation enacting the revenue sharing system as technical option, but also for the national budget, aiming at the two big tools interpreted as main instruments in the federal fiscal system of the country, for getting more balance in the regional development. 
Argentina, in view of the clauses and Articles incorporated into the Supreme Law, 'the regulating laws must lay down (detail) its execution'. This is the task necessary to overcome the 'transitional legal patchwork' to achieve the constitutional objectives.

Considering the data for provincial per capita GDP, the differences among the highest level and the lowest is striking. As usual, the income of CABA exceeds that of the national average many times over, as well as that of the 'have not' jurisdictions. The information shown for the USA, bearing in mind that the USA also has problems of regional inequality, explains the calamitous imbalances registered for Argentina. Therefore, in order to reach a more balanced growth and development in Argentina, the federal fiscal system will need the help of other policies to yield more effective results in the process of achieving ambitious objectives such as 'equivalence of development'. The reduction of the horizontal economic imbalances or the accomplishment of a more even territorial development must result in expanded capacities induced by an increased competitiveness. In such a perspective, systemic competitiveness matters to attain more balanced growth and development.

Given the importance of a new redistribution scheme for revenue sharing, it would also be necessary to develop a new and improved package of coordinated policies, developed in time to achieve a more robust impact in terms of more even territorial development.

Finally, it seems necessary to adopt a combination of regional policy with the fiscal-federal policy presented for the revenue sharing system and its secondary distribution, taking into account redistributive coefficients in the functioning of the pro-rata mechanism.

\section{Bibliography}

Asensio, Miguel A. "Territorial Imbalances and Regional Disparities within a Federal Context: The Case of Argentina." In Federalism, Regionalism and Territory, edited by Stelio Mangiamelli, 93-105. Milano: Giuffre, 2013.

Asensio, Miguel A. Descentralización fiscal en el Cono Sury la experiencia internacional. Buenos Aires: Buyatti, 2006.

Asensio, Miguel A. Federalismo fiscal, Analisis. Fundamentos y caso argentine. Buenos Aires: Ciudad Argentina, 2000.

Asensio, Miguel A. Local Government Finance in Argentina. Washington: The World Bank, 2006.

Asensio, Miguel A. "Subnational Tax Powers in Argentina." Occasional Paper $\mathrm{N}^{\circ} 16$. Ottawa: Forum of Federations, 2015. 
Asensio, Miguel A. "Political Unity and Economic Diversity in the Argentine Federation." In Revisiting Unity and Diversity in Federal Countries: Changing Concepts, Reform Proposals and New Institutional Realities, edited by Alain G. Gagnon and Michael Burgess, 193-205. Leiden and Boston: Brill-Nijhoff, 2018.

Bickerton, James P. "Regional Development in Canada: Fifty Years of Federal Policies and Agencies." International Meeting on Economic and Institutional Trajectories in Federal Countries, March 30-31. Santa Fe, Argentina: International Meeting on Economic and Institutional Trajectories in Federal Countries, 2016.

Bird, Richard M. Federal Finance in Comparative Perspective. Toronto: University of Toronto Press, 1986.

Boudeville, Jacques. Los espacios económicos. Buenos Aires: EudeBA, 1967.

Brown, Jonathan. Historia socieconómica del Rio de la Plata. Buenos Aires: Sudamericana, 1998.

Burgess, Michael and Alain C. Gagnon. Comparative Federalism and Federation, Competing Traditions and Future Directions. Toronto: University of Toronto Press, 1993.

Burgess, Michael and Alain C. Gagnon. General Document Presented at the Montreal Meeting of IACFS on Unity and Diversity in Federal Systems. Montreal, 2015.

Cuadrado Roura, Juán R. and Tomás Mancha Navarro. "Política regional y de cohesión." In Economía de la Unión Europea, edited by Josep M. Jordán Galduf, 465-514. Madrid: Thompson-Civitas, 2008.

Dahlby, Bev and Joanna Roberts. "Fiscal Federalism and Equalization in Canada." In Federalismo fiscal, Experiencia nacional y comparada, edited by Miguel A. Asensio and Pablo M. Garat, 295-320. Santa Fe: Rubinzal y Culzoni, 2011.

Della Paolera, Gerardo and Alan M. Taylor. A New Economic History of Argentina. New York: Cambridge University Press, 2007.

Desideri, Carlo. "Regionalism and Territorial Politics in Italy". In Federalism, Regionalism and Territory, edited by Stelio Mangiamelli, 149-196. Milano: Giuffre, 2013.

Di Tella, Guido and Manuel Zymmelman. Las etapas del desarrollo económico argentino. Buenos Aires: Paidós, 1973.

Díaz Alejandro, Carlos F. Ensayos sobre la historia económica argentina. Buenos Aires: Amorrortu, 1983 .

Díaz Alejandro, Carlos F. "No Less Than One Hundred Years of Argentine Economic History Plus Some Comparisons." In Comparative Development Perspectives: Essays in Honor of Lloyd G. Reynolds, edited by Gustav Ranis, Robert L. West, Mark W. Leiserson and Cynthia Taft Morris, 328-361. Boulder, Colorado: Westview Press, 1984. Ferrer, Aldo. Economía argentina, Etapas de su desarrollo y principales problemas. Buenos Aires: Fondo de Cultura Económica, 2009.

Figueras, Alberto J. "Enfoque regional de la economía argentina: Su estructuración histórica." In El desafío del territorio, Un análisis de las economías regionales, edited 
by Alberto J. Figueras and José L. Arrufat, 37-5o. Córdoba: Asociación Cooperadora de la Facultad de Ciencias Económicas de la Universidad Nacional de Córdoba, 2007.

Figueras, Alberto J. "La competitividad de las economías provinciales." In El desafío del territorio, Un análisis de las economías regionales, edited by Alberto J. Figueras and José L. Arrufat, 296-305. Córdoba: Asociación Cooperadora de la Facultad de Ciencias Económicas de la Universidad Nacional de Córdoba, 2007.

Figueras, Alberto J. and José L. Arrufat. "La regionalización como respuesta a los desafíos sociales y económicos del Siglo XXI." In El desafío del territorio, Un análisis de las economías regionales, edited by Alberto J. Figueras and José L. Arrufat, 319323. Córdoba: Asociación Cooperadora de la Facultad de Ciencias Económicas de la Universidad Nacional de Córdoba, 2007.

Gerchunoff, Pablo and Lucas Llach. El ciclo de la ilusión y el desencanto. Buenos Aires: Crítica, 2015.

Helmsing, Bert A.H.J. “Teorías del desarrollo industrial regional”, Revista eure, Vol. xxv, $\mathrm{N}^{\circ}$ 75, (September 1999): 5-39.

King, Preston. Federalism and Federation. Maryland: The Johns Hopkins University Press, 1982.

Luna, Félix. Buenos Aires y el país. Buenos Aires: Sudamericana, 1978.

Marrama, Vittorio. Política económica y países subdesarrollados. Madrid: Editorial Aguilar, 1961.

Miguez, Eduardo. Historia económica argentina. Buenos Aires: Sudamericana, 2003.

Myrdal, Gunnar. Economic Theory and Underdeveloped Regions. London, Methuen Paperbacks, 1957.

Myrdal, Gunnar. Teoría económica y regiones subdesarrolladas. México: Fondo de Cultura Económica, 1957.

Núñez Miñana, Horacio. Finanzas Públicas. Buenos Aires: Editorial Macchi, 1994.

Perroux, Francois. Nota sobre la noción de polo de crecimiento. Buenos Aires: Consejo Federal de Inversiones, 1956.

Pinto, Julio and Fortunato Mallimaci. La influencia de las religiones en el Estado y la Nación Argentina. Buenos Aires: EudEBA, 2013.

Porto, Alberto. "Análisis comparado de las finanzas de los gobiernos provinciales en la Argentina." In Finanzas Públicas y Desarollo Regional, edited by Luis E. Di Marco, 227-243. Córdoba: Dirección General de Publicaciones de la Universidad Nacional de Córdoba, 1989.

Rapoport, Mario. Historia económica y social de la Argentina. Buenos Aires: Ariel, 2008. Rodríguez, Elena. "Commentary," Desarrollo Económico, Vol. I, N ${ }^{\circ}$ 3, (OctoberDecember 1961): 217-219.

Rofman, Alejandro B. and Luis A. Romero. Sistema socioeconómico y estructura regional en Argentina. Buenos Aires: Amorrortu, 1974. 
Rofman, Alejandro B. Las economías regionales. Buenos Aires: Centro Cultural de la Cooperación Floreal Gorini and Universidad Nacional de Quilmes, 2012.

Salvatore, Ricardo and Carlos Newland. "Between Independence and the Golden Age: The Early Argentine Economy." In A New Economic History of Argentina, edited by Gerardo Della Paolera and Alan M. Taylor, 19-45. New York: Cambridge University Press, 2007.

Strick, John C. "Regulation and Deregulation." In The Handbook of Canadian Public Administration, edited by Christopher Dunn, 263-278. Toronto: Oxford University Press, 2002.

Vázquez Rial, Horacio. Memoria de las ciudades. Buenos Aires 1880-1930. La capital de un imperio imaginario. Madrid: Alianza Editorial, 1996.

Walter, Richard J. Politics and Urban Growth in Buenos Aires: 1910-1942. New York and Cambridge: Cambridge University Press, 1993. 